\title{
Collaborative lesson research: maximizing the impact of lesson study
}

\author{
Akihiko Takahashi ${ }^{1} \cdot$ Thomas McDougal $^{2}$
}

Accepted: 20 December 2015 / Published online: 4 January 2016

(C) The Author(s) 2015. This article is published with open access at Springerlink.com

\begin{abstract}
New common standards for mathematics were adopted by most of the states in the US by 2010. Achieving these standards, however, is a challenge, since they require significant changes in how mathematics is taught. Lesson study (jugyou kenkyuu) is a form of professional development that has been credited for supporting profound changes in teaching in Japan, but its effectiveness outside of Japan has been uneven. From research on school-based lesson study in Japan and from the research on and experience with lesson study in schools in the US, the authors hypothesize that certain institutional structures and practices are important for maximizing its impact, but are sometimes omitted from lesson study outside of Japan. The authors introduce a new term: collaborative lesson research (CLR), defined to include those structures and practices. A three-phase model of school-based CLR, focused on implementation of the new learning standards for mathematics, is being piloted at 15 urban schools in three major school districts in the US. This paper provides details of the pilot program and preliminary results from some of the partner schools.
\end{abstract}

Keywords Curriculum implementation · Lesson study · Mathematics teaching · Common Core State Standards

Akihiko Takahashi

ATakahas@depaul.edu

Thomas McDougal

TFMcDougal@LSAlliance.org

1 DePaul University, Chicago, USA

2 Lesson Study Alliance, Chicago, USA

\section{Introduction}

In 2010, new common standards for K-12 English language arts/literacy (ELA) and mathematics were introduced in the United States to replace the standards that individual states had developed independently. These standards, called the Common Core State Standards, were developed under the auspices of the Council of Chief State School Officers and the National Governors Association Center for Best Practices. Forty-two out of 50 states chose to adopt them (Common Core State Standards Initiative 2010).

Since the adoption of these standards, implementing them has been a challenge. The Common Core State Standards for Mathematics comprise two parts: the content standards, which dictate the specific mathematical topics students should learn in each grade, and the Standards for Mathematical Practice, which describe eight general practices that students should learn in all grade levels. These Standards for Mathematical Practice are not new; they are based on the Process Standards from Principles and Standards for School Mathematics (National Council of Teachers of Mathematics 2000), and several of them go back much further. They include mathematical problem solving, reasoning, and communication. A focus on problem solving in school mathematics was advocated at least as early as 1980 in An Agenda for Action (National Council of Teachers of Mathematics 1980), and was a theme in the Curriculum and Evaluation Standards for School Mathematics (National Council of Teachers of Mathematics 1989). But problem solving, reasoning, and communication remain stubbornly absent from US classrooms.

Education researchers widely agree that developing students' abilities with respect to these practice standards requires a different approach to teaching than what is commonly seen in US classrooms (e.g. National Council of 
Teachers of Mathematics 2014; Stigler and Hiebert 1999). Overall, mathematics instruction in the US has changed very little since the early 1900s (National Research Council 2001; Stigler and Hiebert 2009). Changing what is taught at each grade can probably be addressed by changing the textbooks, but history suggests that changing how mathematics is taught will be more difficult.

Given the lack of progress in US education at changing teaching practices, it is worth considering other models of professional development than what is commonly used. This paper describes an approach being developed and tested in three large urban school districts, based on lesson study (jugyou kenkyuu), in which all teachers of mathematics in a school work together to meet the challenges of implementing both the content and practice standards of the Common Core State Standards.

\section{Jugyou kenkyuu vs. lesson study}

Jugyou kenkyиu, the primary form of professional development in Japan for over a hundred years, was introduced outside of Japan in the late 1990s, translated as "lesson study" (Stigler and Hiebert 1999; Yoshida 1999). The early research articles that introduced lesson study described what Japanese teachers do to improve teaching and learning based on case studies (e.g. Lewis and Tsuchida 1998; Yoshida 1999; Stigler and Hiebert 1999). But those case study reports could not explain much about why Japanese teachers do what they do, or which parts of the process are essential and which parts could be modified.

\subsection{Early attempts}

Based on those reports, researchers, educators, and teachers around the world have attempted to use lesson study to improve mathematics teaching and learning. But almost none of those researchers or educators had observed lesson study in Japan, or had prior experience of doing lesson study themselves. Some of these projects faithfully followed the descriptions of lesson study, and some adapted the process to fit the limited time that most schools were willing to offer. Nevertheless they hoped to replicate the success of lesson study in Japan at transforming traditional teacher-centered instructional practice to student-centered instruction that focuses on mathematical thinking and problem solving (e.g., Hart et al. 2011).

The effectiveness of these projects is unclear. Only a few cases have been documented in which there was strong evidence of impact of lesson study on teaching and learning (e.g., Lewis et al. 2006). Perhaps the clearest such evidence comes from the Lesson Study Group at Mills college, where researchers conducted a randomized, controlled trial of lesson study supported by mathematical resource kits, and found a significant impact on both teachers' and students' mathematical knowledge (Lewis and Perry 2014). In a recent review of 643 studies of mathematics professional development using a process modeled on What Works Clearinghouse guidelines-some using lesson study and some not—only the Lewis and Perry study, and one other, met scientific criteria and showed impact on student learning (Gersten et al. 2014).

In Japan, whenever the national curriculum is revised, lesson study plays a critical role in the effective implementation of the new curriculum across the country (Takahashi 2014b). We believe that lesson study can support the implementation of the Common Core State Standards here in the US. But it will be important to understand why lesson study has been less consistently impactful outside of Japan-whether there are important aspects of lesson study as practiced in Japan that are getting "lost in translation" and can be fixed, or whether the problem is due to cultural differences that cannot be fixed.

\subsection{Understanding lesson study}

For Japanese teachers, lesson study is an integral part of teaching, "like the air" as one teacher put it (Fujii 2014), and, as with the air, it has been hard to see what lesson study is really made of. But some aspects of Japanese lesson study have become visible as a result of flawed attempts to use it elsewhere and as a result of recent studies of jyugyou kenkyuu in Japan.

\subsubsection{Insights through counterexamples}

Fujii (2014) examines how lesson study is practiced in some of the African countries supported by Japanese educators, and notes that many aspects of lesson study as practiced in Japan are left out. The same occurs in the US. For example, many projects omit the first crucial phase of lesson study, kyouzai kenkyuu, ${ }^{1}$ that helps teachers gain knowledge and insight into mathematics and student thinking (Takahashi et al. 2005; Lewis et al. 2011).

The first author of this article, who himself practiced lesson study as a teacher in Japan, has had plenty of experience observing activities referred to as "lesson study" which, in his eyes, looked very different from what he used to do. One school district, for example, decided to fit an entire lesson study cycle into 1 day. In the morning, a team of teachers came together to spend 30 min planning a lesson. They taught the lesson to students and reported

${ }^{1}$ Kyouzai kenkyuu is discussed in more details in Sects. 2.2.3 and 4.2 . 
what they observed. That afternoon, they modified the lesson plan in $30 \mathrm{~min}$ and taught the revised lesson. On the surface, this 1-day process included all the components of lesson study that are described in most journal articles and resources. But the typical duration of one lesson study cycle in a Japanese elementary school is more than 5 weeks (Murata and Takahashi 2002) - it is certainly never done in just one day.

Another example from a different district shows a profound misunderstanding of the purpose of lesson study. After a public research lesson and post-lesson discussion, the teachers who planned the lesson commented that they had not learned much from the process because they had already done lesson study six times on that same lesson. This team thought that the purpose of lesson study was to create a perfect lesson plan. The true purpose of lesson study, however, is to gain new knowledge for teaching and learning, not to perfect a lesson plan. In fact, re-teaching a research lesson even once is not a common practice in Japan (Fujii 2014).

\subsubsection{Investigating lesson study in Japan}

In addition to these examples of lesson study being misinterpreted, and thus shedding light on what lesson study is and is not, researchers have recently investigated how and why Japanese teachers use lesson study and how the process of lesson study helps Japanese teachers build their knowledge and expertise of mathematics teaching and learning. This work contributes to a greater understanding among Japanese as well as non-Japanese educators of the conditions necessary for schools and teachers to conduct lesson study effectively (e.g. Lewis et al. 2006; Murata and Takahashi 2002; Watanabe 2002; Fernandez and Yoshida 2004; Shimizu 2002).

An important finding is that lesson study in Japan is most often conducted as part of a highly structured, schoolwide project, involving all or nearly all of a school's staff, aimed at addressing a common teaching-learning challenge (Takahashi 2014b; Takahashi and McDougal 2014). This contrasts with most lesson study projects outside of Japan, which are done by enthusiastic volunteer teachers independent of their school professional development activities.

Another important finding from recent research concerns the role of supporting professionals (koushi), often referred to in English as "knowledgeable others." A knowledgeable other is someone from outside of the planning team with deep expertise in the content, often deep expertise in teaching, and much experience with lesson study. Many lesson study projects in the US are done by teachers without a knowledgeable other, but lesson study in Japan almost always includes a knowledgeable other who provides final comments at the post-lesson discussion, and sometimes a different knowledgeable other who may draw attention to key issues during the planning phase (Watanabe and WangIverson 2005). Lewis argues that knowledgeable others from outside the planning team may be critical to scaling up successful school-based lesson study in the US (Lewis et al. 2006). Based on a study by Watanabe (2005), Takahashi (2014a) conducted a case study that looked at three experienced knowledgeable others in Japan in order to better understand their role, and noted many ways in which their final comments helped participants connect the lesson with larger issues in mathematics and pedagogy.

\subsubsection{Identifying important elements of Japanese lesson study}

Lesson study has been the primary mechanism of professional development for both prospective teachers and practicing teachers since the Japanese public education system started (Lewis 2000; Lewis and Tsuchida 1998; Murata and Takahashi 2002; Takahashi 2000; Takahashi and Yoshida 2004; Makinae 2010; Yoshida 1999). The forms of lesson study vary depending upon its purpose; the most common form of lesson study takes place within a single school as a school-based professional development program (Yoshida 1999). A very common purpose of school-based lesson study is to seek practical ideas for the effective implementation of the Japanese national curriculum, or course of study (Murata and Takahashi 2002).

Japanese teachers begin lesson study by carefully reading the course of study, reading relevant research articles, and examining available curricula and other materials, a process called kyouzai kenkyuu, or "study of materials for teaching" (Takahashi and Yoshida 2004; Takahashi et al. 2005). Based on their kyouzai kenkyuu, they then design a lesson focused on a problematic topic while also addressing a broader research theme related to teaching and learning. This lesson, known as a "research lesson" (kenkyu jugyou), is taught by a teacher from the planning team while the other team members - and other educators who are not on the planning team-observe. The planning team and observers then conduct a post-lesson discussion (kenkyuu kyougikai) focusing on how students responded to the lesson in order to gain insights into the teaching-learning process and into how the course of study should be implemented (Lewis and Tsuchida 1997).

From the "lesson study" activities that so clearly deviate from lesson study as practiced in Japan, and from the research that specifically analyzes the nature of lesson study in Japan, the following features emerge as likely to be important for lesson study to be most effective:

1. Participants engage in lesson study to build expertise and learn something new, not to refine a lesson. 
2. It is part of a highly structured, school-wide or sometimes district-wide process.

3. It includes significant time spent on kyouzai kenkyuu.

4. It is done over several weeks rather than a few hours.

5. Knowledgeable others contribute insights during the post-lesson discussion and during planning as well.

The remainder of this paper describes our on-going work in a large urban school district in which we are applying these principles to help schools implement the new Common Core State Standards.

\section{What we have been learning}

Since 2002, the authors have been working in a large US school district to help teachers improve mathematics teaching and learning using lesson study. For a long time, most of this work, like most lesson study in the US, involved small teams of enthusiastic volunteers engaged in lesson study outside of the professional development structures of their schools. Indeed, the teachers often came from different schools. Because of the first author's many years of experience with lesson study as a teacher in Japan, we are confident that the work done by these teachers captured the most important aspects of lesson study, and the teachers benefited accordingly. But the benefits of these efforts have often dissipated as teachers moved away, schools changed administrations, or teachers just grew tired of trying to practice lesson study without adequate time or support from administrators and colleagues. Despite the fact that public research lessons have been going on in the city for 12 years, all the schools that piloted lesson study in the early years discontinued after a few years.

When the state adopted the Common Core State Standards in 2010, with full implementation to begin in the fall of 2014, the professional development climate changed. Many teachers and administrators recognized the magnitude of the changes that they need to make, both in terms of content and instruction. Furthermore, they recognized that the professional development they were getting was not adequate, although they weren't always sure what was missing. A study of professional development in three large US cities found no consistent impact on teacher growth (TNTP 2015). Most of that professional development focused on building teachers knowledge of teaching; but to meet the full challenge of the new standards, teachers need professional development that focuses on developing their expertise in teaching, i.e. their ability to apply new knowledge in the classroom and to teach in ways that will develop students' problem-solving, reasoning, and communication skills as called for by the new standards.
The authors are now working with five public elementary schools where the administrations not only support lesson study, but want to make it a routine component of professional development for all teachers. All of these schools are high-poverty schools whose students face many challenges. Expanding lesson study to all teachers can be challenging, but our experience with these schools has shed valuable light on what it takes to make it happen. We share our preliminary findings through case studies of these schools, where the work is still in progress.

\subsection{Five cases of lesson study in urban public schools}

Teachers from over 30 different schools in the city have been engaged in lesson study since 2002, but, as mentioned previously, these efforts were almost all disconnected from school initiatives and eventually faded away. But now five public elementary schools, serving students from kindergarten through grade 8 , are using lesson study as their major form of professional development for mathematics. In this section, we describe the evolution of lesson study at the five schools and describe what we are learning from their work.

\subsubsection{School A}

School A first opened in the fall of 2009, and lesson study began there when two teachers and the math/science coordinator attended a lesson study workshop during the summer of 2010. Over the next several years, the math/science coordinator was a low-key but consistent advocate of lesson study, recruiting other teachers and working side-byside with them to plan research lessons. The authors of this article served as knowledgeable others, providing feedback on draft lesson plans, observing their research lessons, facilitating the post-lesson discussions, and providing final comments. And, crucially, the school administration attended the research lessons and provided class coverage so that other teachers could attend the lessons as well.

Besides the considerable social skill wielded by the math/science coordinator and the encouragement and logistical support provided by the administration, the early establishment of a good school research theme helped motivate teachers to get involved. The math/science coordinator and the teachers who participated in lesson study decided early on that they wanted to improve their students' ability to articulate their reasoning-this began before the new standards were adopted but aligned well with one of the Standards for Mathematical Practice, "Give a viable argument and critique the reasoning of others". They made this goal more concrete by connecting it to student note-taking and teachers' use of the board. They thought that if students could learn to use their notebooks 
to record their own thinking, the notebooks would support them in making oral arguments. And, if students could learn to record the thinking of other students, this would be a step toward thinking critically about others' reasoning. But for students to learn to use their notebooks in this way, teachers would have to model it for them on the board. Also, teachers could use the board strategically to display different student solutions as a way to support discussion about those solutions.

Teachers at school A agreed that they wanted to work on student communication and recognized that lesson study would be a way for them to develop the classroom practices (including use of the board) that they would need to support their students. Teachers realized, however, that if they wanted the students to talk about mathematics, they needed something substantive to talk about. This led the teachers to the idea of "teaching mathematics through problem solving", an approach widely used in Japan (Shimizu 2003). They felt that their current curriculum did not support this way of teaching, so they turned to an English translation of a Japanese textbook, Mathematics International (Fujii and Iitaka 2012). They recognized the challenge of teaching math through problem solving and, again, saw lesson study as a way to support each other in learning to teach that way.

The teachers started with a high level goal, which was to have students give viable arguments and critique the reasoning of others, and generated a hypothesis which connected that goal to three concrete changes in practice: teach students to use notebooks; organize work on the board more deliberately in order to support student note-taking and discussion about students' ideas; and design lessons around challenging tasks. This concrete hypothesis turned an abstract goal into an achievable goal.

Test score results encouraged the teachers and faculty to continue: growth in mathematics as measured at the end of 2014 was at the 67 th percentile. But even more encouraging were the mathematical conversations that were now taking place in the classrooms. Even kindergarten students would present an idea, then turn to their classmates and ask if they agreed or disagreed. By spring 2015, 20 of the 27 teachers of mathematics in the school $(74 \%)$ had been involved in planning at least one research lessoneven the principal and assistant principal had each taught a public research lesson-and the administration was making it clear that participating in lesson study would soon be expected of every teacher.

\subsubsection{School B}

In 2012, school B got a new principal and assistant principal. The assistant principal had traveled to Japan to learn about lesson study when she was a math coordinator at another school, and had taught a public research lesson. In the first year at school B, she recruited a small group of teachers to work with her to plan a research lesson, which she taught on a professional development day with the entire faculty observing.

Lesson study spread slowly at first. In the summer following the first research lesson, one team of five teachers attended a lesson study workshop to plan a research lesson, which they conducted publicly the following spring. They and the assistant principal encouraged other teachers to get involved, and in the next summer, 2014, two teams comprising 10 teachers attended the lesson study workshop again. But in the 2014-2015 school year, every teacher of mathematics but one (24 teachers) participated in planning a research lesson, and there was at least one research lesson in each of grades $\mathrm{K}, 1,2,3$, and 8 (the latter was planned by teachers from grades $4-8$ ).

Several forces helped lesson study take hold. Clearly the assistant principal played a critical leadership role, similar to the role of the math specialist at school A, by participating on the first planning team, teaching the first research lesson, and gently but persistently encouraging teachers to try lesson study. Teachers who participated early on told their colleagues about how valuable it was. The principal also provided important support by paying for teachers to attend the summer workshops and an annual lesson study conference, and by providing release time so that the teachers could conduct their research lessons and so that other teachers could attend them.

The school also established a partnership with school A, whose teachers opened their research lessons. Through this process, teachers at school B learned about the Japanese textbook and decided to start using it. According to the assistant principal, having access to a good curriculum made lesson study much more satisfying for them.

\subsubsection{School C}

At school C, lesson study began as it often has elsewhere, with a small volunteer group of teachers. In this case, it was originally three teachers (later, four) who taught grades 3 and 4. The principal, who was enthusiastic about lesson study, supported their efforts by giving them release time during the school day for planning and teaching their research lessons. Over time, the students of these teachers, mostly second language learners, scored increasingly well on the state math test. At least four times, on staff development days, the teachers conducted a research lesson that was observed by the entire faculty, as a way to share their learning with their colleagues. The teachers also planned and taught, several times, public lessons at a major annual lesson study conference.

But despite the successes of these teachers with their students, and despite their occasional efforts to persuade 
their colleagues to try lesson study, for several years lesson study failed to expand beyond the core group.

Two of those teachers and the principal strategically planned a different approach in 2014-2015. At the end of summer 2014, during professional development days before school began, the principal asked the experienced teachers to lead a grade K-1 team and a grade 2-3 team in developing research lessons, and required the other teachers from grades K-3 to participate. Not only did those teams successfully complete their research lessons, each team decided to do a second research lesson in the spring (one in math, one in literacy). The principal reports that teachers show signs of investment in the process-such as choosing to attend research lessons at other schools, visiting other classrooms, planning together more frequently, and consulting the Japanese textbook.

\subsubsection{School D}

School D first admitted students in the fall of 2009, using space in an under-utilized school building alongside an existing elementary school; by fall 2013 it had taken over the entire building. Like at school B, the lesson study effort was led by the assistant principal. In the summer of 2013, he and three teachers - one from kindergarten, one from grade 3, and one special education teacher-attended the summer lesson study workshop and developed a research lesson for grade 3, which they tested in the following October. A second team, comprising the 3rd grade teacher from the first team and two new members, planned a second research lesson for the spring, with release time and paid after-school time. In summer 2014, three teams attended the lesson study workshop, and there were a total of five research lessons during the following school year. Out of 21 teachers who taught math, spanning grades Pre-K to 8,16 were involved in planning a research lesson during 2014-2015. But, despite the success at expanding lesson study as a school-wide practice, the impact of their work has been limited by the lack of a coherent school-wide research theme, a problem the administration plans to address.

\subsubsection{School E}

At school E, lesson study was imposed top-down. Although such an approach is frequently disastrous, special circumstances helped it work in this case.

The school was a so-called "turn-around" school because of historically low academic performance: in previous years, only $50 \%$ of students had met state standards in reading and mathematics. As part of the turn-around, the entire staff was replaced; all the teachers and administrators were new to the school in fall 2014, and almost all of the teachers were in their first year or two of teaching. The school had extra funds as part of the turn-around and the administration was investing heavily in professional development, paying the teachers for after-school time to work in professional learning communities focused on math and literacy.

Being inexperienced and in a tough situation, the teachers were struggling despite this extra support. Mid-year formative test results suggested that students were making promising progress in literacy but not in mathematics. So in early January 2014, the administration invited one of the authors to give a presentation to the faculty about teaching to the new standards. According to the principal, teachers were impressed by the ideas but were also intimidated, wondering how to implement them. A few weeks later, the authors gave a presentation on lesson study and how it could help them improve their practice, and the administration described their plan to make lesson study the focus of the already-occurring math meetings, with support from the authors.

The school faculty established a school-wide research theme, which, similar to the one at school A, was about students giving viable arguments. Then, during the rest of that winter and spring, four teams planned and conducted one research lesson each for grades K, 2, 4, and 7. Throughout the process, the administration reinforced the message that everyone was learning together, and teachers celebrated each research lesson by going out for food and drink. (Following the custom in Japan, the teacher of the research lesson ate and drank for free).

End-of-year test scores showed strong growth in mathematics (66th percentile), which encouraged the administration and faculty to continue lesson study in the following year and helped the administration obtain approval from their superiors to do so.

\subsection{Lessons learned from the five schools}

Juxtaposing school $\mathrm{C}$ with the other four schools offers valuable twin lessons about obstacles and strategies for establishing lesson study as a school-wide practice.

One obstacle was that school $\mathrm{C}$ had no lesson study leader. Despite his enthusiasm for lesson study, the principal was swamped with the demands of his job and competing mandates coming from his superiors. He also respected the teacher-led character of lesson study, and was concerned that a top-down mandate would undermine longterm change. Meanwhile, the core group of teachers, who were quite busy with their day-to-day teaching, didn't see themselves as instructional leaders (nor, probably, did their more-experienced colleagues view them that way), despite their experience teaching public lessons at their school and at conferences. In contrast, school A had a math/science 
coordinator and schools B, D, and E each had an assistant principal who actively promoted lesson study.

But in the spring of 2014, all four members of the core group received National Board Certification. Two of those members then helped lead a summer workshop on using lesson study to learn to teach math through problem solving. This appears to have developed their confidence and self-image as instructional leaders, and helped their principal to view them that way as well.

Another obstacle may have been the school's overall success with its students. Although $99 \%$ of the students at school C qualify for free or reduced lunch, and the majority of students are learning English as a second language, the students' math scores at the school have been very high: in 2012 over $80 \%$ of students at every grade level met or exceeded state standards, and scores were rising. Based on these metrics, current practices were successful, so there was little motivation to change. The original core group of three teachers learned about teaching math through problem solving when they were together at a different school several years before, and this had become their shared research theme, but the rest of the faculty had no such theme to motivate their participation in lesson study-and they still do not, which may be an obstacle to expanding lesson study further.

Based on these case studies, then, the following elements seem to be important catalysts of school-wide lesson study:

- enthusiasm for lesson study from the school principal, clearly communicated to the faculty;

- a persistent lesson study advocate in addition to the principal;

- a compelling school-wide goal for teaching and learning;

- a commitment on the part of the school administration to provide time for lesson study, through use of funds, staff, and district-mandated professional development time.

In the rest of this paper, we will look at how schools can organize to use lesson study to drive durable, long-term change in teaching and learning and meet the expectations of the new standards.

\section{Collaborative lesson research (CLR): a powerful form of lesson study}

Lesson study is not an end in itself, but a process for accomplishing specific teaching-learning goals. From the first author's experience, from research on lesson study in Japan (e.g. Takahashi 2014b; Takahashi and McDougal
2014; Fujii 2014; Takahashi 2011a, 2014a), and from our experience with the schools described above, we hypothesize that certain institutional structures and practices are important for maximizing the impact of lesson study. In order to differentiate these collective structures and practices from other, less-effective implementations of lesson study, we have coined a new term: collaborative lesson research (CLR). ${ }^{2}$ As a form of lesson study, CLR is an investigation undertaken by a group of educators, usually teachers, using live lessons to answer shared questions about teaching and learning. We define collaborative lesson research (CLR) as having the following components:

1. A clear research purpose

2. Kyouzai kenkyuи

3. A written research proposal

4. A live research lesson and discussion

5. Knowledgeable others

6. Sharing of results

We now elaborate on each of these.

\subsection{A clear research purpose}

One of the jyugyou kenkyuu counterexamples in Sect. 2.2.1 above involves a lesson that the team had refined through multiple trials. In that instance, the team was not trying to learn anything new; the lesson was more a demonstration of what they had developed. In contrast, CLR is research, a search for a solution to a teaching-learning problem.

The research focus of CLR usually has two layers. One layer involves the teaching of specific content: how can we design a lesson so that students learn such-and-such concept or skill better than they have in the past? Thus the topic of the research lesson should usually present some challenge for students or teachers. The second layer involves a broad teaching-learning goal that is shared by the CLR community, and that goes beyond any particular topic or grade level and may even be cross-disciplinary. This second layer is referred to as the research theme.

There is no widely shared definition of "research theme", but in our view a research theme describes (a) a desired outcome for students, and (b) an entry point for achieving that outcome. At schools A and E, for example, teachers seek to improve their students' ability to give a viable argument and to critique the reasoning of others; their entry point is teaching students to use journals to record their own ideas and the ideas of others. A complete

\footnotetext{
2 The term is drawn from Catherine Lewis's original translation of jugyou kenkyuu as "Lesson Research" in the late 1990s, which we revive in order to emphasize the research purpose of jugyou kenkyuu.
} 
statement of the theme should be short enough to be memorable, such as "For students to be able to clearly explain their thinking and consider the ideas of others through the support of their own journals".

We have seen how a compelling research theme has been an important motivator at three out of the five schools described above. Teachers are conscious of a gap between the outcomes they desire for their students and what they have been able to achieve, and they are eager for the opportunity to work together to close that gap. Because their research theme is relevant to all grade levels, the teachers see how they can benefit by observing research lessons with students older or younger than their own, and engaging in lesson study allows them to contribute to their professional community.

\subsection{Kyouzai kenkyuu}

Kyouzai kenkyuu, the careful study of academic content and teaching materials, is integral to lesson study as practiced in Japan (Takahashi et al. 2005; Takahashi and Yoshida 2004); it is analogous to a literature review in scientific research. It involves an investigation of the intended learning trajectory related to the topic from lower to higher grades, through a review of the standards and curriculum, and research into teaching and learning issues such as typical misunderstandings around the topic. Kyouzai kenkyuu also includes consideration of possible tools, manipulatives, or materials that may be used, and possible tasks that may be presented to students. Thorough kyouzai kenkyuu helps avoid "reinventing the wheel", making it more likely that CLR will contribute new knowledge to the education community.

One obstacle for teachers at the five schools, as for all teachers in the US, is the quality of available materials to support kyouzai kenkyuu, especially compared to the materials available to Japanese teachers (Lewis et al. 2011). Initially, no curricula were available that aligned well with the new standards, and most US textbooks are designed to support didactic instruction, which does not develop students as independent problem solvers. Thus, like the teachers at school A, when they conducted their kyouzai kenkyuu, the teachers at the other four schools usually studied the same Japanese textbook series.

\subsection{A written research proposal}

A CLR planning team creates a written document, called the lesson research proposal, to communicate what the team learned from their kyouzai kenkyuu, and to explain their instructional thinking. It includes learning goals for a unit, an overview of the unit, a detailed teaching-learning plan for one particular lesson within the unit (the research lesson), a rationale for the design of the unit and research lesson, and a clear statement of how the research lesson aims to address the research theme and the learning goals. In our experience, a thorough lesson research proposal may be 9 pages long. The authors developed a template document to guide CLR teams in organizing their lesson study work and in writing their proposal. ${ }^{3}$

\subsection{A live research lesson and post-lesson discussion}

Based on the lesson plan in the research lesson proposal, one member of the team teaches the research lesson, observed by the entire planning team and by additional members of the CLR community. Observers are responsible for collecting data on how the lesson impacts the students, relative to the research theme and the learning goals. A video recording of the lesson can be useful for some purposes, but CLR requires observations from multiple viewpoints, so video does not substitute for live observation.

As soon as practical after the research lesson, observers share data and discuss implications, especially with respect to the learning goals of the lesson and the research theme. ${ }^{4}$ The primary goal of the discussion is to gain insights into teaching and learning and to inform the design of future lessons, not to revise the lesson plan. These discussions generally benefit from a moderator, someone not on the planning team, who helps focus the discussion on important issues and keeps the conversation grounded in data.

\subsection{Knowledgeable others}

As discussed above, "knowledgeable others", persons with both extensive knowledge of the topic and extensive experience with CLR, are invited by the team to help them go beyond what they know. Ideally a CLR community needs two knowledgeable others: one for supporting proposal development and another for providing the final comments at the end of the post-lesson discussion.

During planning, a knowledgeable other may help the team identify instructional examples to review, valuable resources in the form of articles or results from other CLR work, and may give feedback on the proposal. Besides having extensive knowledge of the subject matter and the topic, this knowledgeable other should be familiar with the school's curriculum and students. An experienced teacher or a content coach who often works at the school may play

\footnotetext{
${ }^{3}$ http://LSAlliance.org/public_docs/lesson_research_proposal_template.docx.

${ }^{4}$ For this activity we avoid the term "debriefing", which is used by some, because it denotes a simple reporting out of observations, potentially without discussion. We use instead the admittedly more cumbersome term "post-lesson discussion".
} 
the role of this kind of knowledgeable other. At school A, this role is played primarily by the math/science coordinator; at the other schools, one (or both) of the authors joins some of the lesson study meetings and provides guidance. As teachers deepen their knowledge of content through lesson study, we expect that they will be able to provide this service to each other.

Another knowledgeable other is needed at the research lesson. At the end of the post-lesson discussion, he or she is expected to highlight important events from the research lesson that were not discussed, and make connections between the lesson and new knowledge from research and standards. The knowledgeable other also provides suggestions to the CLR community of possible steps they could take toward accomplishing their research theme (Takahashi 2014a; Watanabe and Wang-Iverson 2005).

\subsection{Sharing of results}

CLR is not just for the improvement of teaching and learning within the team, but also for improving teaching and learning more broadly. Thus CLR should include a structure or process for disseminating what is learned from each research lesson to a larger community. Simply inviting people from outside of the planning team to observe and discuss the research lesson is one valuable way that CLR teams contribute to the learning of other educators while benefiting from the additional eyes and expertise that the additional observers bring. In addition, the team may distribute their research lesson proposal, which encapsulates the team's research and their instructional ideas, and can be useful to other educators. This document is made more powerful through the addition of a written reflection by the team, completed within a few days after the research lesson, which describes what they learned from the live lesson observation and post-lesson discussion about their research hypothesis, mathematics, student thinking, teaching, etc. At the five schools we are working with, the administrators have found ways to enable teachers who are not on the planning team to participate in observing and discussing the research lessons, and have often invited teachers from the other schools to observe these lessons as well.

We chose these six defining characteristics of CLR based on findings from research on lesson study outside of Japan and jugyou kenkyuu in Japan, and our own experience of working with schools. As defining characteristics, we consider them required elements of CLR: if any of them is missing, then the activity cannot be called CLR.

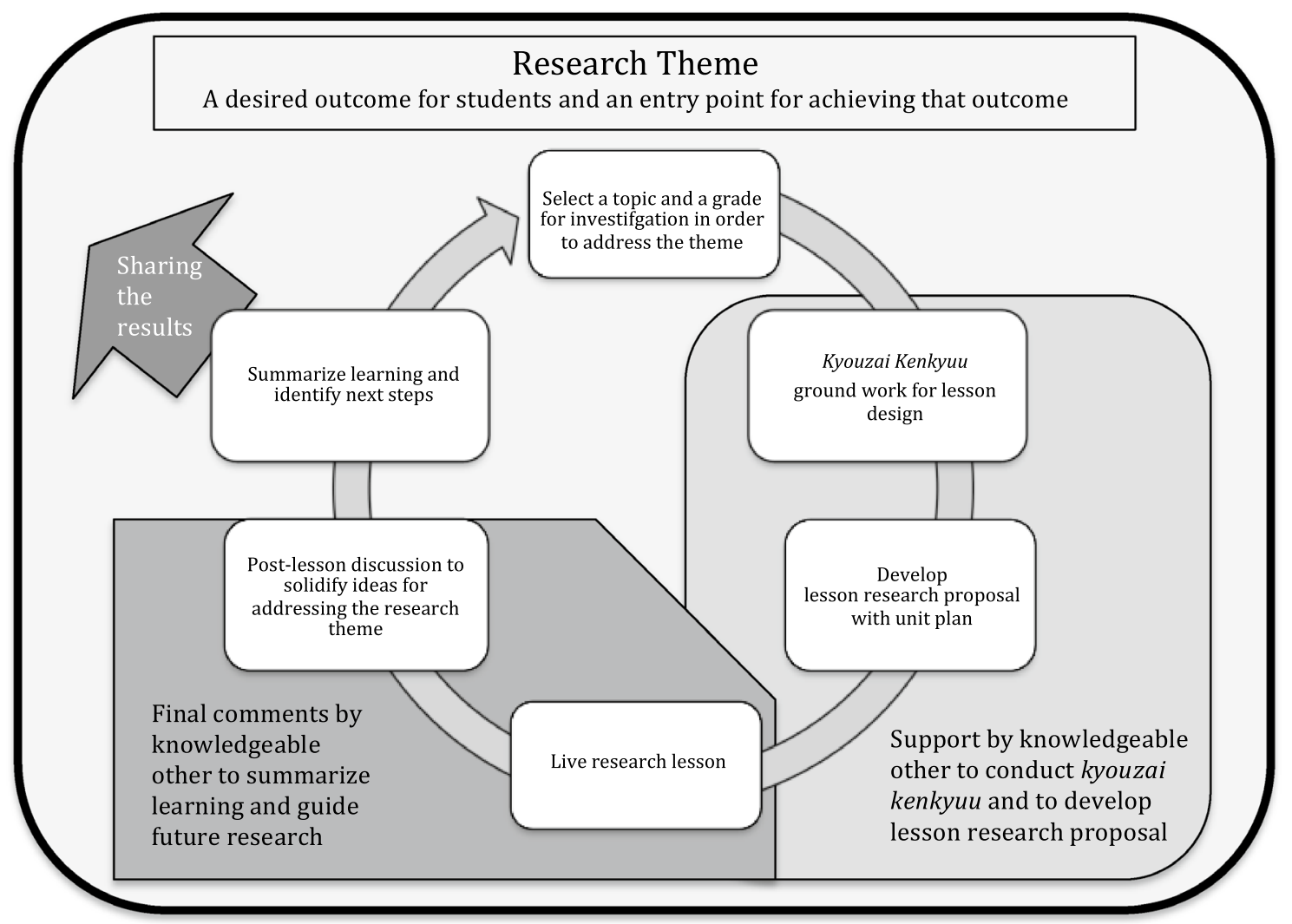

Fig. 1 Collaborative lesson research 
In addition, we note that although CLR does not have to be done more than once, it almost always is, because the research theme is usually difficult to accomplish and is broader than any single topic. Lessons learned from one CLR cycle lead to revised theories about how to address the theme, or adjustments in the theme itself, which lead to another CLR cycle involving a different topic perhaps at a different grade level (see Fig. 1).

\section{Implementing school-based CLR to support implementation of new standards}

As mentioned above, a very common purpose of schoolbased lesson study in Japan is to solve the problem of implementing revisions to the national standards. CLR, as we define it, is not necessarily a whole-school endeavor. But similar to schools in Japan, we believe that US schools can-and perhaps must-use CLR school-wide to fully implement the Common Core State Standards. The authors are currently testing the following three-phase model of school-based CLR for implementing the new standards in the five schools described above.

\subsection{The first phase}

To be ready for the full implementation of school-based CLR, some ground work needs to be done before the school year begins, either during summer professional development or at the end of the previous school year.

To maximize the impact of the CLR work of teachers within the school, some coordination is needed. This is the role of the school research steering committee, and forming this committee is an important part of the first phase of school-based CLR. Typically, the committee should comprise teachers from different grade levels at the school and a teacher leader or content specialist. It is responsible for leading the school's CLR efforts, ensuring that what is learned at each research lesson is disseminated to the rest of the school, and maintaining cohesiveness of ideas across the grades (Takahashi 2014b; Takahashi and McDougal 2014). The research steering committee is expected to be responsible for the following:

- developing a master plan for the school research;

- scheduling and leading meetings to find strategies to address the school's research theme based on the ideas of the teachers;

- planning, editing, and publishing school research reports, including those for a research open house; and

- arranging for knowledgeable others to present lectures, teach demonstration lessons, and give final comments at research lessons.
One of the first tasks of the research steering committee is to create a draft schedule of research lessons for the following year.

Another important step in phase one is to establish a research theme, which will focus teachers' efforts on implementing the new standards. This research theme should come naturally out of differences or gaps between the school's educational goals and the standards on the one hand, and the actual state of the students on the other. A draft research theme can be developed by the research steering committee, but it should be approved by consensus of all the teachers of mathematics. A Research Conception Map (Fig. 2) makes explicit the relationship between the school's educational goals, the standards, and the actual state of the students.

Three or more "CLR teams" should be created, subgroups of teachers by grade band (e.g. K-2, 3-5, and 6-8) that are responsible for planning research lessons. Each CLR team should create a description of an ideal student profile appropriate for their grade band in terms of the research theme. Coming up with an ideal student profile is a typical practice in school-based lesson study because it provides observable behaviors or outcomes by which the success of lesson study can be measured. Then, each team should come up with a hypothesis about concrete steps they might take in everyday lessons that will move students toward the ideal profile.

\subsection{The second phase}

The second phase of school-based CLR consists of multiple iterations of the CLR cycle shown in Fig. 1. Each CLR team conducts two CLR cycles during the year to test and refine their ideas about how to overcome the issues that the team identified during the first phase. So each school will have six CLR cycles in the year, and each teacher will be a part of two CLR cycles as a member of the team, planning and conducting the research lessons. In addition, each teacher at the school is encouraged to participate in research lessons and post-lesson discussions conducted by the other CLR teams four times in each year. This means that each teacher of mathematics at the school will engage in discussion regarding the school research theme, in the context of a research lesson, almost every month during the school year. In this way, schools will become the place for teachers to learn to improve mathematics teaching and learning, and implementing the new standards will be a common, collaborative endeavor.

At the end of a CLR cycle, the team summarizes their learning from the research lesson and submits a report to the research steering committee. When all three teams have submitted their reports, the research steering committee 
Fig. 2 Research conception map for school-based collaborative lesson research (adapted from Lewis and Hurd 2011, p. 50)
School's Educational Goals -

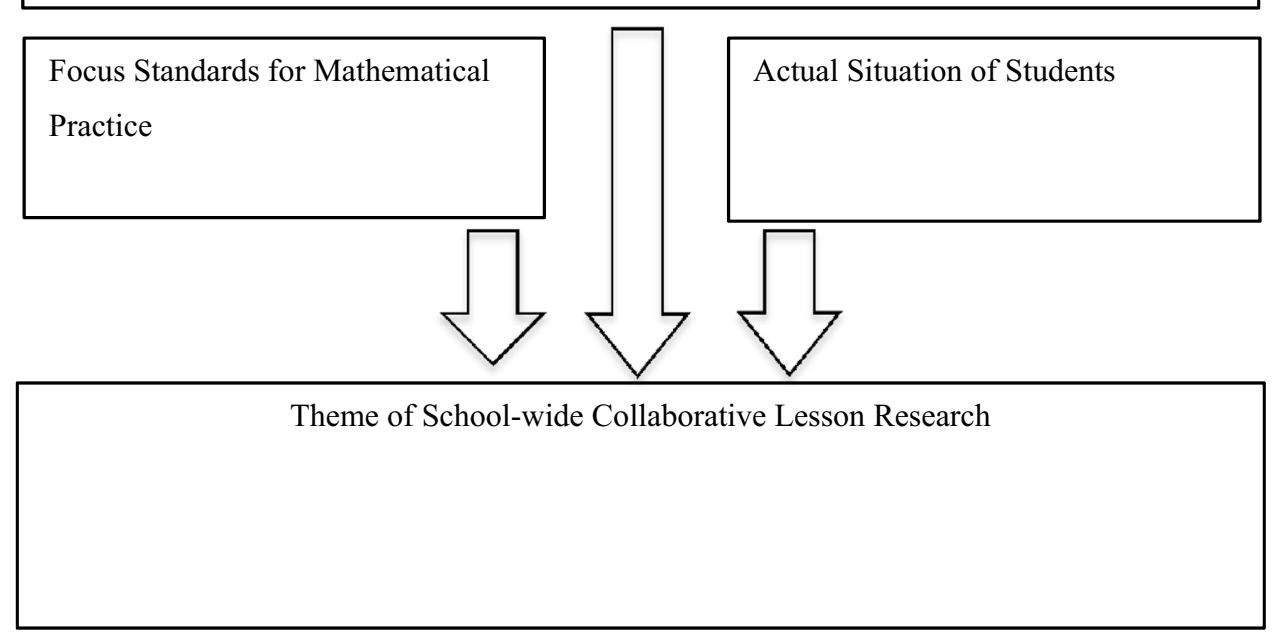

Ideal Profile of Students

\begin{tabular}{|l|l|l|}
\hline $\begin{array}{l}\text { Lower Grade Band } \\
\text { Students will be }\end{array}$ & Upper Grade Band \\
\end{tabular}

Hypotheses about how to support these student qualities

\begin{tabular}{|l|l|l|}
\hline Lower Grade Band & Middle Grade Band \\
\end{tabular}

reviews the reports in order to consolidate learning, and shares their findings back to the teams. Figure 3 shows the major activities during the second phase.

\subsubsection{The third phase}

The third phase of the school-based CLR project occurs in the next school year. It includes the same activities as in the second phase, but the purpose of the CLR cycles in this third phase is to refine and consolidate what was learned during the second phase. As is typical in Japan, the school publishes a report on their work, which includes:
- how the school came up with the theme;

- all research lesson plans from the 2 years with summaries of the post-lesson discussions and key learnings; and

- a summary of a wrap-up discussion at the end of the school-based CLR project.

\section{The next step}

In the summer of 2002, a joint US/Japan seminar entitled "The professionalization of teachers through Lesson 


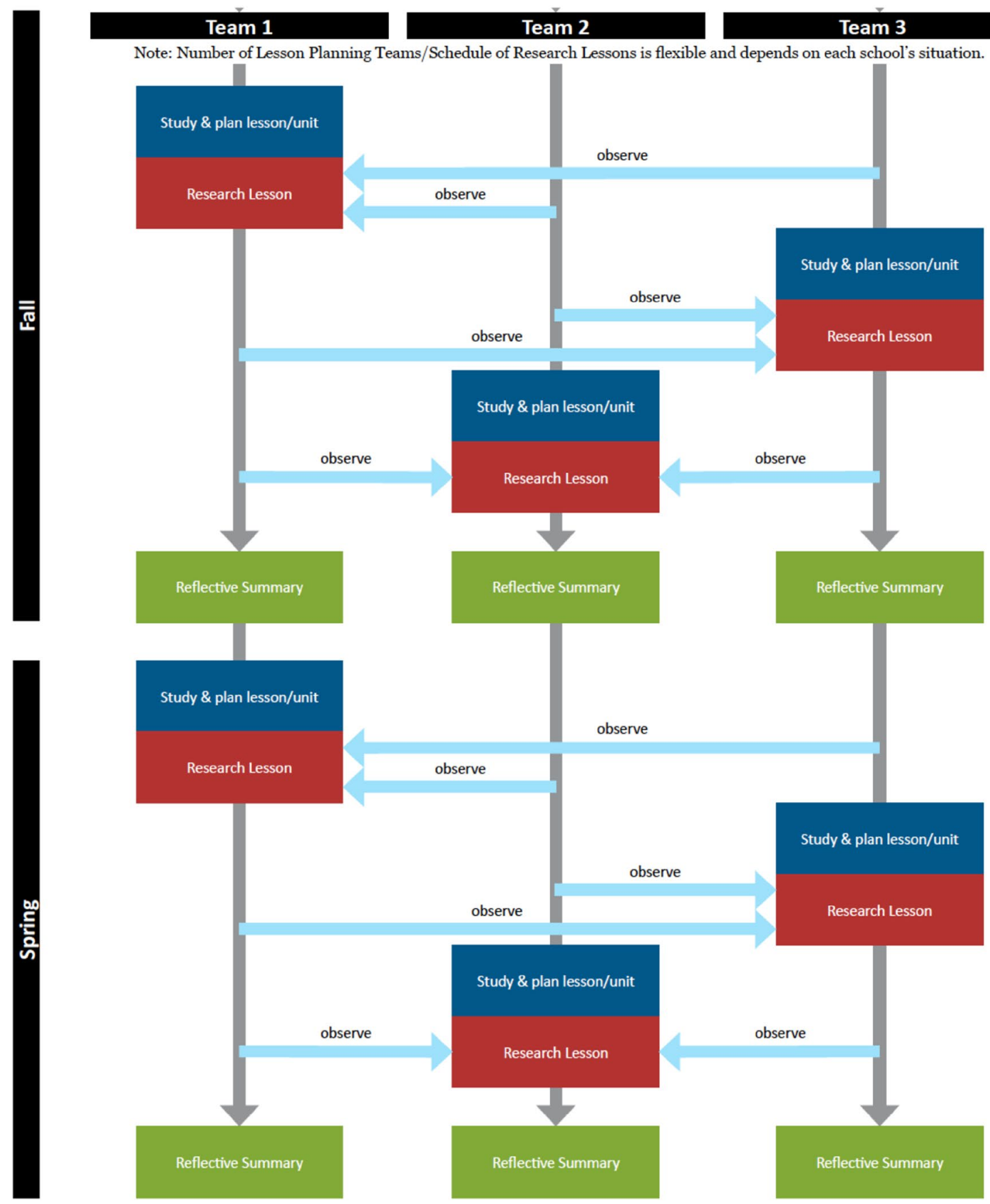

Fig. 3 Second phase: multiple CLR cycles during the school year

Study" was held at Park City, Utah. Although one of the major goals of the seminar was to clarify the mechanisms and operating principles of lesson study, Japanese mathematics education researchers and teachers did not then have clear definitions to distinguish authentic lesson study from lesson study-like activities. After more than a decade of attempts to use lesson study outside of Japan, important mechanisms and operating principles of effective lesson study are becoming clear. By coining the term
"Collaborative Lesson Research" and clearly defining it, the authors hope to guide educators who wish to use lesson study to improve teaching and learning.

In January 2015, the authors joined a project designed to help schools in three large urban districts use CLR schoolwide to implement the Common Core State Standards. We began piloting the process in 5 schools in one district, following the three phases described above, and plan to duplicate the process in ten additional schools in the other two 
districts. The goal is to develop a model and system of supports for establishing school-based CLR.

A few months into the second phase of this project, many of the components of CLR are in place in the five lead schools, and the majority if not all of the teachers of mathematics at every school except school $\mathrm{C}^{5}$ are involved in lesson study. Both teachers and administrators are expressing great satisfaction with the learning taking place; the following statements by teachers are some examples:

Lesson study has enabled me to reflect upon my own teaching not only individually, but within a supportive team. It has helped push me to be more introspective and ask myself the question 'why' within my planning and instructional decisions.

Lesson study has completely changed my approach to mathematics instruction.... My math pedagogical knowledge has increased tremendously. It is through lesson study that I've been able to truly reflect and gain insights into children's mathematical understandings/misunderstandings.

We are loving lesson study. This could be transformative for our school.

As for the CLR components not yet in place, teachers or administrators are beginning to recognize the need for them. For example, after one recent post-lesson discussion, the principal asked about ways to share valuable insights from that discussion with teachers who were not presentthe "sharing of results" component in our list above. Thus we are optimistic that collaborative lesson research fits the needs of the teachers and may become a primary form of professional development in the schools for improving mathematics teaching and learning.

We also have reason to expect that this work can be sustained and will yield clearly-identifiable improvements in students' learning. School-wide lesson study has been sustained at other US schools for periods of 5 years or more, and has shown impact on student achievement (Lewis et al. 2006). Accounts of these school-wide lesson study efforts (Lewis 2002; Lewis and Hurd 2011) and video of key elements of the process ${ }^{6}$ illustrate the power of teachers developing a shared research theme and conducting lesson study cycles to investigate and improve instruction, guided by their theme. Although it is premature to assess the impact on student learning at the five lead schools, the viability and effectiveness of implementing the school-based CLR

\footnotetext{
$\overline{5}$ At school C only the K-3 teachers are currently involved in Lesson Study.

${ }^{6} \mathrm{http}: / /$ lessonresearch.net/resources2.html.
}

model could be examined through the collection of the data in phase 3 of this project.

Acknowledgments This publication is based in part on a project funded by the Bill and Melinda Gates Foundation. The findings and conclusions contained within are those of the authors and do not necessarily reflect positions or policies of the Bill and Melinda Gates Foundation.

Open Access This article is distributed under the terms of the Creative Commons Attribution 4.0 International License (http://creativecommons.org/licenses/by/4.0/), which permits unrestricted use, distribution, and reproduction in any medium, provided you give appropriate credit to the original author(s) and the source, provide a link to the Creative Commons license, and indicate if changes were made.

\section{References}

Common Core State Standards Initiative (2010). Common Core State Standards for mathematics. http://www.corestandards.org/ the-standards/mathematics.

Fernandez, C., \& Yoshida, M. (2004). Lesson study: a Japanese approach to improving mathematics teaching and learning. New York: Routledge.

Fujii, T. (2014). Implementing Japanese Lesson Study in foreign countries: misconceptions revealed. Mathematics Teacher Education and Development, 16(1), 65-83.

Fujii, T., \& Iitaka, S. (2012). Mathematics international (grade $1-$ grade 9). Tokyo: Tokyo Shoseki.

Gersten, R., Taylor, M. J., Keys, T. D., Rolfhus, E., Newman-Gonchar, R. (2014). Summary of research on the effectiveness of math professional development approaches. Washington, DC: US Department of Education, Institute of Education Sciences, National Center for Educational Evaluation and Regional Assistance, Regional Educatioal Laboratory Southeast.

Hart, L. C., Alston, A., Murata, A. (Eds.). (2011). Lesson study research and practice in mathematics education. New York: Springer.

Lewis, C. (2000). Lesson study: the core of Japanese professional development. In AERA annual meeting, April 2000.

Lewis, C. (2002). Lesson study: a handbook of teacher-led instructional change. Philadelphia: Research for Better Schools, Inc.

Lewis, C., \& Hurd, J. (2011). Lesson study step by step: how teacher learning communities improve instruction. Portmouth: Heinemann.

Lewis, C., \& Perry, R. (2014). Lesson study with mathematical resources: a sustainable model for locally-led teacher professional learning. Mathematics Teacher Education and Development, 16(1), 22-42.

Lewis, C., Perry, R., Friedkin, S. (2011). Using Japanese curriculum materials to support lesson study outside Japan: toward coherent curriculum. Educational studies in Japan: international yearbook: ESJ 6(Classrooms and Schools in Japan), 5-19.

Lewis, C., Perry, R., Hurd, J., O’Connell, M. P. (2006). Lesson study comes of age in North America. Phi Delta Kappan, 88(04), 273-281.

Lewis, C., \& Tsuchida, I. (1997). Planned educational change in Japan: the shift to student-centered elementary science. Journal of Educational Policy, 12, 313-331.

Lewis, C., \& Tsuchida, I. (1998). A lesson is like a swiftly flowing river: how research lessons improve Japanese education. American Educator, 22(4), 12-17, 50-52. 
Makinae, N. (2010) The origin of lesson study in Japan. In Y. Shimizu, Y. Sekiguchi, K. Hino (Eds.), The 5th East Asia Regional Conference on Mathematics Education: In Search of Excellence in Mathematics Education, Tokyo, 2010 (Vol. 2, pp. 140-47). Japan Society of Mathematics Education.

Murata, A., \& Takahashi, A. (2002). Vehicle to connect theory, research, and practice: how teacher thinking changes in districtlevel lesson study in Japan. Proceedings of the twenty-fourth annual meeting of North American chapter of the international group of the Psychology of Mathematics Education, pp. 1879-1888.

National Council of Teachers of Mathematics. (1980). An agenda for action: recommendations for school mathematics of the 1980s. Reston: National Council of Teachers of Mathematics.

National Council of Teachers of Mathematics. (1989). Curriculm and evaluation standards for school mathematics. Reston: National Council of Teachers of Mathematics.

National Council of Teachers of Mathematics. (2000). Principles and standards for school mathematics. Reston: National Council of Teachers of Mathematics.

National Council of Teachers of Mathematics (2014). Principles to actions: ensuring mathematical success for all. Reston.

Shimizu, Y. (2002). Sharing a new approach to teaching mathematics with the teachers from outside the school: The role of lesson study at "fuzoku" schools. In: US-Japan Cross Cultural Seminar on the Professionalization of Teachers Through Lesson Study, Park City, Utah, July 2002.

Shimizu, Y. (2003). Problem solving as a vehicle for teaching mathematics: a Japanese perspective. In F. K. Lester (Ed.), Teaching mathematics through problem solving: grades pre K-6 (pp. 205214). Reston: National Council of Teachers of Mathematics.

Stigler, J., \& Hiebert, J. (1999). The teaching gap: best ideas from the world's teachers for improving education in the classroom. New York: Free Press

Takahashi, A. (2000). Current trends and issues in lesson study in Japan and the United States. Journal of Japan Society of Mathematical Education, 82(12), 15-21.

Takahashi, A. (2011). The Japanese approach to developing expertise in using the textbook to teach mathematics rather than teaching the textbook. In Y. Li \& G. Kaiser (Eds.), Expertise in mathematics instruction: an international perspective (pp. 197-219). New York: Springer.

Takahashi, A. (2014a). The role of the knowledgeable other in lesson study: examining the final comments of experienced lesson study practitioners. Mathematics Teacher Education and Development, 16(1), 4-21.

Takahashi, A. (2014b). Supporting the effective implementation of a new mathematics curriculum: a case study of school-based lesson study at a Japanese public elementary school. In I. Y. Li \& G. Lappan (Eds.), Mathematics curriculum in school education (pp. 417-441). New York: Springer.

Takahashi, A., \& McDougal, T. (2014). Implementing a new national curriculum: a Japanese public school's two-year Lesson-Study Project. In A. R. McDuffie, \& K. S. Karp (Eds.), Annual perspectives in mathematics education (APME) 2014: using research to improve instruction (pp. 13-21). National Council of Teachers of Mathematics.

Takahashi, A., Watanabe, T., Yoshida, M., \& Wand-Iverson, P. (2005). Improving content and pedagogical knowledge through Kyozaikenkyu. In P. Wang-Iverson \& M. Yoshida (Eds.), Building our understanding of lesson study (pp. 101-110). Philadelphia: Research for Better Schools.

Takahashi, A., \& Yoshida, M. (2004). How can we start Lesson Study? Ideas for establishing lesson study communities. Teaching Children Mathematics, 10(9), 436-443.

TNTP. (2015). The mirage: confronting the hard truth about our quest for teacher development. New York: Brooklyn.

Watanabe, T. (2002). The role of outside experts in lesson study. In C. Lewis (Ed.), Lesson study: a handbook of teacher-led instructional imporvement. Philadelphia: Research for Better Schools.

Watanabe, T., \& Wang-Iverson, P. (2005). The role of knowledgeable others. In P. Wang-Iverson \& M. Yoshida (Eds.), Building our understanding of lesson study (pp. 85-91). Philadelphia: Research for Better Schools.

Yoshida, M. (1999). Lesson study: a case study of a Japanese approach to improving instruction through school-based teacher development. Dissertation, University of Chicago, Chicago. 